\title{
Anastomosis Between the Deep Branch of Ulnar Nerve and a Branch of the Median Nerve (Cannieu-Riché Anastomosis) and Thenar Muscles Innervation. Anatomical Study and Clinical Implications
}

\author{
Anastomosis entre el Ramo Profundo del Nervio Ulnar y un Ramo del Nervio Mediano (Anastomosis \\ de Cannieu-Riché) e Inervación de la Eminencia Tenar. Estudio Anatómico e Implicaciones Clínicas
}

Edie Benedito Caetano ${ }^{1}$; Luiz Angelo Vieira ${ }^{2}$; Yuri da Cunha Nakamichi ${ }^{3}$; Maico Minoru Sawada ${ }^{3}$; Renato Alves de Andrade ${ }^{3}$ \& Mauricio Tadeu Nakasone ${ }^{4}$

CAETANO, E. B.; VIEIRA, L. A.; NAKAMICHI, Y. C.; SAWADA, M. M.; ANDRADE, A. A. \& NAKASONE, M. T. Anastomosis between the deep branch of ulnar nerve and a branch of the median nerve (Cannieu-Riche anastomosis) and thenar muscles innervation. Anatomical study and clinical implications. Int. J. Morphol., 36(1):7-13, 2018.

SUMMARY: The aim of this paper was to report the incidences of the anastomosis between deep branch of ulnar nerve and a branch of the median nerve commonly named Cannieu-Riché anastomosis (CRA) and thenar muscles innervation. The anatomical dissection of 80 limbs from 40 fresh adult cadavers were performed in the Department of Anatomy at the Medical School of the Catholic University of São Paulo. The incidence of CRA and thenar muscle innervation were studied. The CRA was found in all of the dissected hands $(100 \%)$. The abdutor pollicis brevis and the opponens pollicis muscle are innervated exclusively by median nerve in all dissected hands. The superficial head of flexor pollicis brevis was innervated by the median nerve in of 56 the hands $(70 \%)$, in $24(30 \%)$ it had double innervation (median nerve and deep branch of ulnar nerve). The deep head of flexor pollicis brevis were absent in 11 hands (14 $\%$ ), in 52 hands (65\%), a double innervation was observed. In 14 (17.5\%) exclusively by deep branch of ulnar nerve and in 3 hands (3.6 $\%$ ) exclusively by a branch of median nerve. The oblique head of adductor pollicis muscle was innervated only by deep branch of ulnar nerve in 66 hands $(82 \%)$ of dissected hands, $14(17.5 \%)$ had a double innervation. The transverse head of adductor pollicis was innervated exclusively by deep branch of ulnar nerve in 77 hands $(96.4 \%)$, and in $3(3.6 \%)$ had a double innervation. According to our study the pattern of innervation was more frequent in relation to the flexor pollicis brevis muscle and should be considered as a normal pattern, in that the superficial head receives innervation of branches of median nerve, and the deep head receives innervation of deep branch of ulnar nerve and branches of median nerve (dual innervation). The abductor pollicis brevis and opponens pollicis received innervation exclusively by median nerve. Both the oblique and transverse head of adductor pollicis exclusively by ulnar nerve. The RCA was found in all of the dissected hands $(100 \%)$.

KEY WORDS: Median nerve; Ulnar nerve; Hand/Innervation.

\section{INTRODUCCIÓN}

The basic anatomy of the median and ulnar nerves in the upper limb, particularly in the hand is well described in textbooks. The variety of clinical aspects observed in the isolated lesions of median and ulnar nerves, does not agree with the classic pattern of innervation of the muscles from the thenar region. A better knowledge of the anatomical variations of these nerves helps to understand both anatomic variations and paradoxic complaints of sensory and motor loss of the patients. The authors have reviewed the anatomic and clinical literature. Cannieu-Riché anastomosis (CRA) was first described by Cannieu (1896) and Cannieu (1897) It is a neural connection between the deep branch of ulnar nerve and branches of median nerve at the thenar eminence. CRA has been considered to carry motor branches between median and ulnar nerves. Axons derived from these two nerves cross to deliver motor innervation to the intrinsic

${ }^{1} \mathrm{PhD}$ of the Department of Orthopedics of the Catholic University of São Paulo, Brazil.

${ }^{2}$ Master Degree of the Department of Orthopedics of the Catholic University of São Paulo, Brazil.

${ }^{3}$ Resident of the Department of Orthopedics of the Catholic University of São Paulo, Brazil.

${ }^{4}$ Fellow research of the Department of Orthopedics of the Catholic University of São Paulo, Brazil. 
CAETANO, E. B.; VIEIRA, L. A.; NAKAMICHI, Y. C.; SAWADA, M. M.; ANDRADE, A. A. \& NAKASONE, M. T. Anastomosis between the deep branch of ulnar nerve and a branch of the median nerve (Cannieu-Riche anastomosis) and thenar muscles innervation. Anatomical study and clinical implications. Int. J. Morphol., 36(1):7-13, 2018.

muscles of the hand. The presence of this anastomosis can cause a risk of iatrogenic injury during surgical procedures, and difficulties in the interpretation of electrophysiological studies for diagnoses of neuropathies (Roy et al., 2015). These anatomical variations should be differentiated from the incomplete nerve lesions (Falconer \& Sppiner, 1985). In particular, carpal tunnel syndrome has been associated with exacerbated or diminished symptoms in the presence of these anastomoses (Iyer \& Fenichel, 1976). The cause, nature, incidence and direction of these fibers of CRA, are relatively unknown. Although unknown, the cause of CRA is generally believed to be aberrant development in early embryogenesis. There are wide discrepancies regarding prevalence of CRA and the thenar muscles innervation based on different methods of investigation that have produced increased results, such a eletromyography studies, anatomical studies, nerve block, and clinical examinations were used. Clinical and electromyography studies suggest that thenar muscles can receive dual innervation from median and ulnar nerves (Highet, 1943; Forrest, 1967). Similarly, the dual innervation of the superficial head of the flexor pollicis brevis (FPB) directly by the deep branch of the ulnar nerve is also a variation that can modify the conduction pathway (Gupta \& Michelsen-Jost, 2012). These variations allow aberrant exchange of axons between the median and ulnar nerves. They can change the composition of the nerves in the distal part of the upper limbs, thereby affecting the nerve supply in the hand (Sarikcioglu \& Sindel, 2000). So we have undertaken an anatomic study to further their understanding of the thenar muscles innervation and this neural communication. According to our findings we report the incidence of Cannieu-Riché anastomosis and the thenar muscles innervation

\section{MATERIAL AND METHOD}

Eighty hands of 40 fresh adult cadavers where dissected from 1983 to 2015 . In all subjects, both hands were studied. Careful dissections were performed under high magnification (with a surgical microscope) to allow fine dissections with a special reference to the incidence of CRA and thenar muscles innervation. The ages ranged from 17 to 68 years, and the sex distribution was 36 males and 4 females that were available in the Department of Anatomy of the Medical School of the Catholic University of São Paulo, Brazil. An initial pilot study consisting of the dissection of 4 hands from 2 fresh cadavers was performed to familiarize us with the regional anatomy of the palmar surface of the hand, and it is not included in this paper. The results were recorded by photography and drawings. These dissections were performed through a palmar carpal tunnel- type incision that extended distally along the palmar surface of the hand. The palmar skin, subcutaneous tissue and palmar fascia were removed. The median nerve was identified at the proximal edge of the transverse carpal ligament, the ligament was divided, and the branches were distally dissected to each thenar muscle. The ulnar nerve was also identified in the wrist proximal to the Guyon canal, and its deep motor branch was followed distally to its communication with branches of the median nerve, we used a $2.5 \mathrm{X}$ magnifying glass. The dissection was then inspected under a microscope using 10- to 16-fold magnification mainly to identify the intramuscular communication. We investigated carefully the innervation of each thenar muscle. Schematic drawings of the pieces were created and systematically photographed.

\section{RESULTS}

The Cannieu-Riché anastomosis was found in all 80 of the dissected hands (100\%). In all hands, we found that the anastomotic branch of the ulnar nerve always originated from the deep branch (Fig. 1). The branches of the median nerve originated from the tennar branch in 35 hands (Fig. 1). In 24 limbs, the anastomotic fascicles originated from the separated of the median nerve at the level of its division at the distal edge of the transverse carpal ligament (Fig. 2). In 17 limbs, the anastomotic branch originated from the radial collateral nerve of the thumb (Fig. 3). In 4 (5\%) observations, we identified the anastomotic branch as originating from the common digital nerve, which branched into the ulnar collateral nerve of the thumb and the radial collateral of the index (Fig. 4). In 3 cases, we found that the fascicles that originated from the median nerve originated in two different places (Fig. 5). We did not identify the branch of the anastomosis coming from the digital collateral branches of the index finger in our dissections. Branches originating from median nerve always were lateral and dorsal to the tendon of the flexor pollicis longus passing between the tendon and the first metacarpal and originating from the motor branch or a common collateral digital nerve of the thumb. (Table I).

The extra muscular CRA we found in 57 hands (72 \%) (Fig.1), intramuscular CRA in 19hands (23\%) (Fig. 3). In four hands $(5 \%)$ we found intra and extra muscular anastomosis (Fig. 6). The anastomosis was noted within the belly of superficial head of (FPB) in 17 hands (22.5\%) (Fig. 3) and within the belly of deep head of FPB in 37 hands (46.5 $\%$ ) (Fig. 5). The anastomosis has also been noted to occur deep within the oblique head of AdP muscle in 7 hands (9 $\%$ ) (Fig. 7). The neural communication within the first 
CAETANO, E. B.; VIEIRA, L. A.; NAKAMICHI, Y. C.; SAWADA, M. M.; ANDRADE, A. A. \& NAKASONE, M. T. Anastomosis between the deep branch of ulnar nerve and a branch of the median nerve (Cannieu-Riche anastomosis) and thenar muscles innervation. Anatomical study and clinical implications. Int. J. Morphol., 36(1):7-13, 2018.

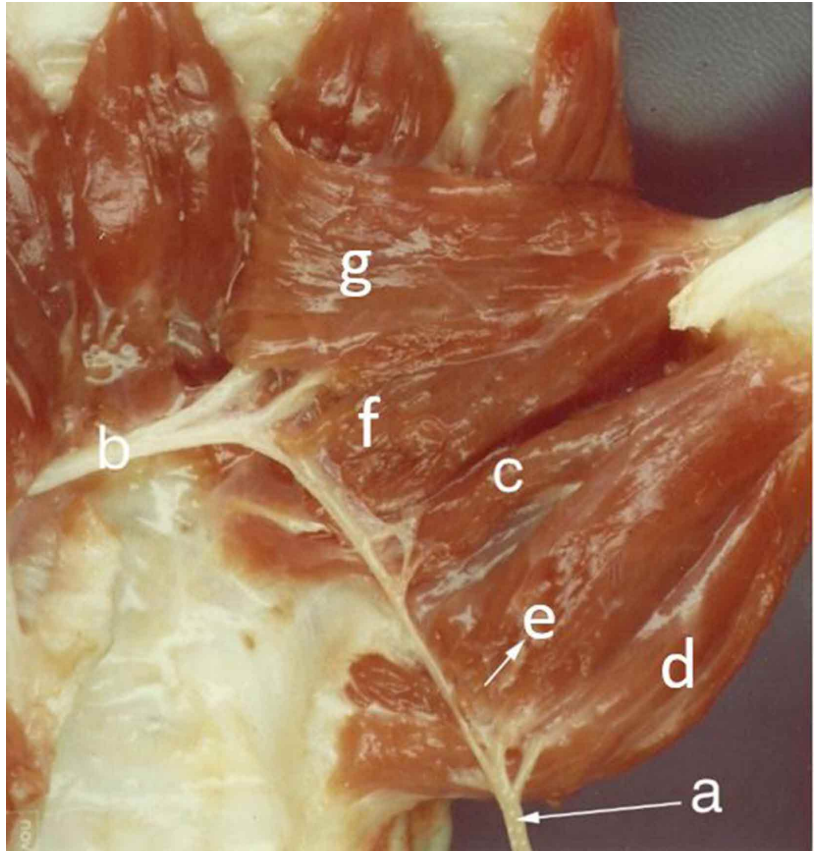

Fig.1. Extramuscular anastomoses; (a) Recurrent branch of median nerve; (b) Deep branch of ulnar nerve; (c) Deep head of FPB (double innervation); (d) Abdutor pollicia brevis muscle; (e) Superficial head of FPB; (f) Oblique head of Adutor pollicis muscle; (g) Transverse head of Adutor pollicis muscle.

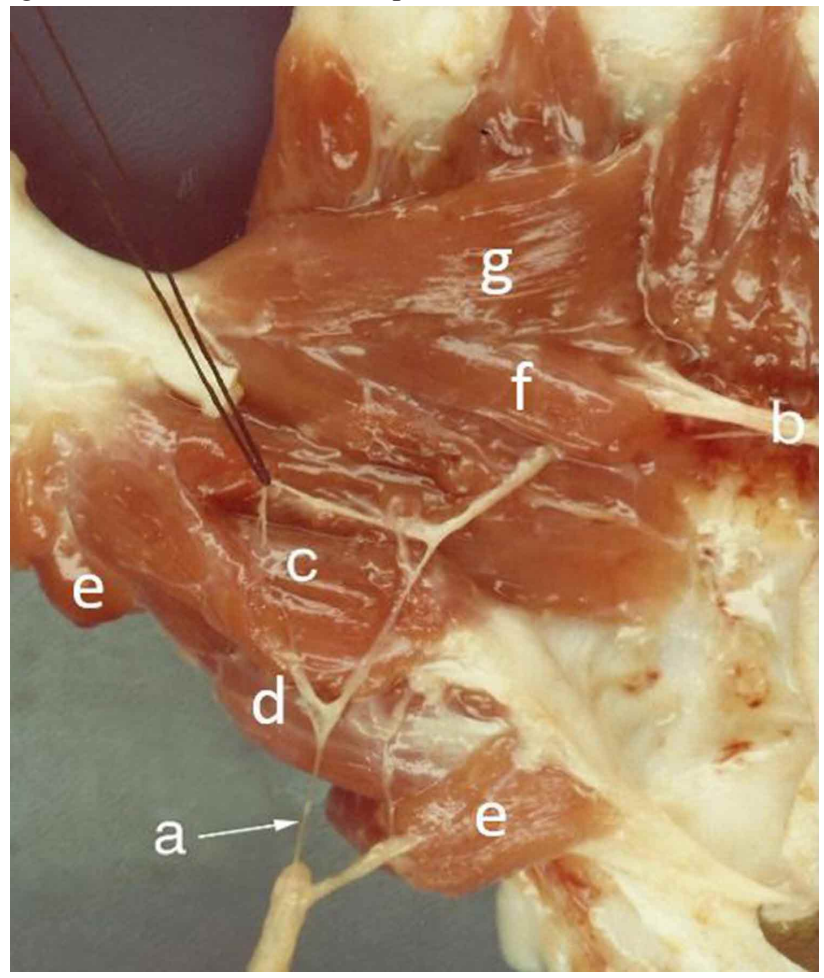

Fig. 2. Extramucular anastomoses; (a) Isolated branch of median nerve; (b) Deep branch of ulnar nerve; (c) Superficial head of FPB (double innervation); (d) Oponens pollicis muscle; (e) Abdutor pollicis brevis muscle; (f) Oblique head of Adutor pollicis muscle; (g) Transverse head of Adutor pollicis muscle. lumbrical were not found in our dissections. The abdutor pollicis brevis (AbPB) and the OP muscle are innervated exclusively by the branches of median nerve in all dissected limbs. (Fig. 2). The superficial head of flexor pollicis brevis was innervated by branches of the median nerve in 56 hands (70 \%) (Fig. 6). In 24 (30\%) the superficial head had double innervation from median nerve and deep branch of ulnar nerve (Fig. 2). The deep head of flexor pollicis brevis showed a different find: In $52(65 \%)$ limbs a double innervation occurred (Fig. 6). In 14 (17.5\%) exclusively by deep branch of ulnar nerve (Fig. 2) and in 3 (3.6 \%) exclusively by branches of median nerve (Fig. 7). In 11 (13.5\%) limbs the deep head is absent (Fig. 8) The oblique head of adutor pollicis muscle was innervated only by deep branch of ulnar

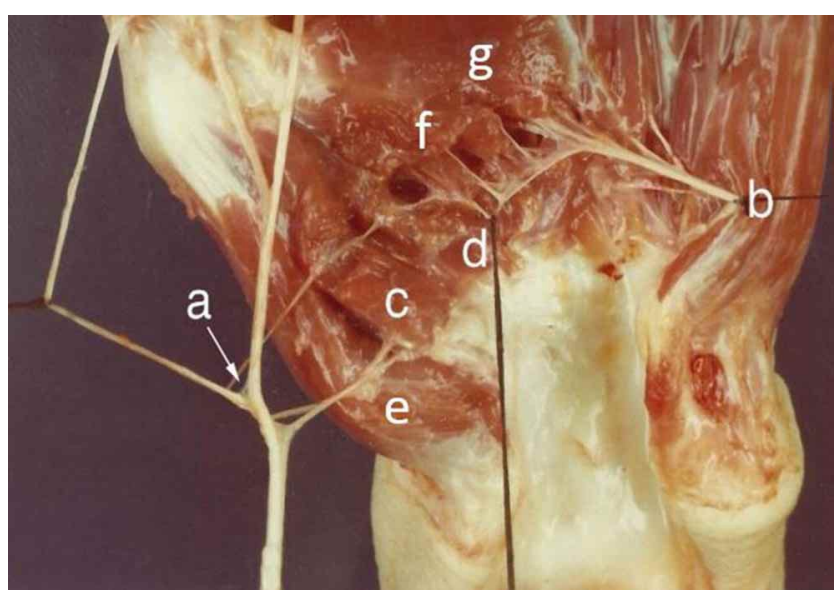

Fig. 3. Intramuscular anastomoses; (a) Collateral radial branch of the thumb; (b) Deep branch of ulnar nerve; (c) Superficial head of FPB and (d) Deep head of FPB (double innervation); (e) Abdutor pollicis brevis muscle; (f) Oblique head of Adutor pollicis muscle; (g) Transverse head of Adutor pollicis muscle.

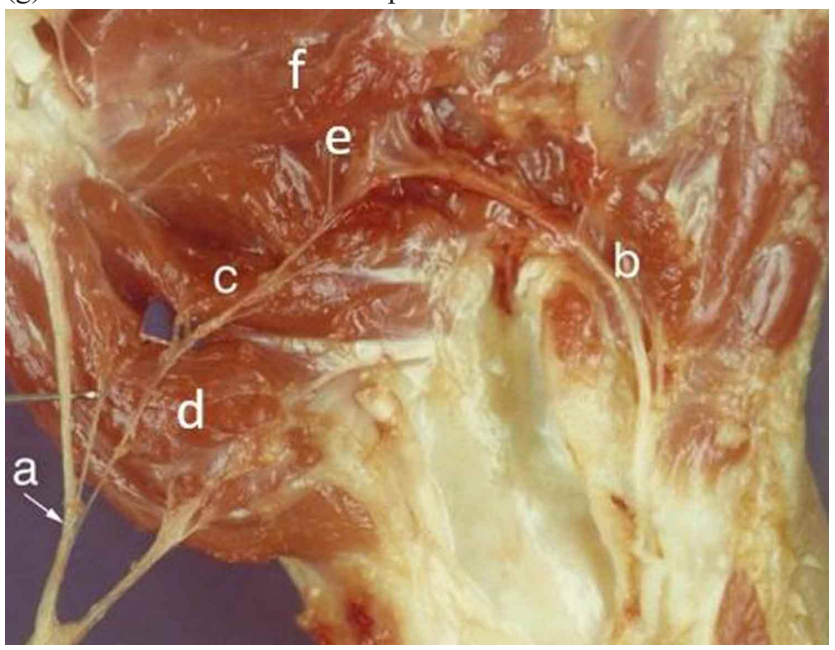

Fig. 4. Extramucular anastomoses; (a) First common digital branch of median nerve; (b) Deep branch of ulnar nerve; (c) Deep head of FPB (double innervation); (d) Superficial head of FPB; (e) Oblique head of Adutor pollicis muscle (double innervation); (f) Transverse head of Adutor pollicis muscle. 
CAETANO, E. B.; VIEIRA, L. A.; NAKAMICHI, Y. C.; SAWADA, M. M.; ANDRADE, A. A. \& NAKASONE, M. T. Anastomosis between the deep branch of ulnar nerve and a branch of the median nerve (Cannieu-Riche anastomosis) and thenar muscles innervation. Anatomical study and clinical implications. Int. J. Morphol., 36(1):7-13, 2018.

Table I. Distribution of median and ulnar innervation to the thenar muscles.

\begin{tabular}{|c|c|c|c|c|c|}
\hline & Median Nerve & Ulnar nerve & \multicolumn{2}{|c|}{ Double innervation } & absent \\
\hline & & & & & \\
\hline Opponens pollicis muscle & 80 limbs $(100 \%)$ & & & & \\
\hline Superficial head of flexor pollicis brevis & 56 limbs $(70 \%)$ & & 24 limbs & $(30 \%)$ & \\
\hline Deep head of flexor pollicis brevis & $3 \operatorname{limbs}(3.6 \%)$ & 14 limbs $(17.5$ & 52 limbs & $(65 \%)$ & 11 limbs (13.5\%) \\
\hline Oblique head of addutor pollicis & & 66 limbs $(82.5$ & 14 limbs & $(17.5$ & \\
\hline Transverse head of addutor pollicis & & 77 limbs $(96.4$ & 3 limbs & $(3.6 \%)$ & \\
\hline
\end{tabular}

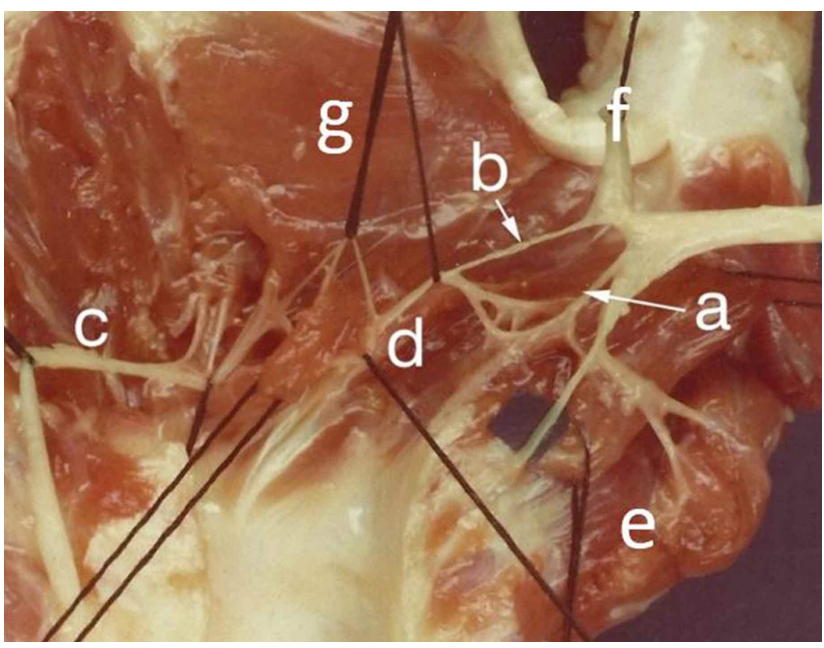

Fig. 5. Intramuscular anastomoses; Two branches of median nerve; (a) Recurrent branch of median nerve; (b) Branch of Collateral radial branch of the thumb; (c) Deep branch of ulnar nerve; (d) Deep head of FPB (double innervation); (e)Abdutor pollicis brevis; (f) Oblique head of Adutor pollicis muscle; ( $\mathrm{g}$ ) Transverse head of Adutor pollicis muscle.

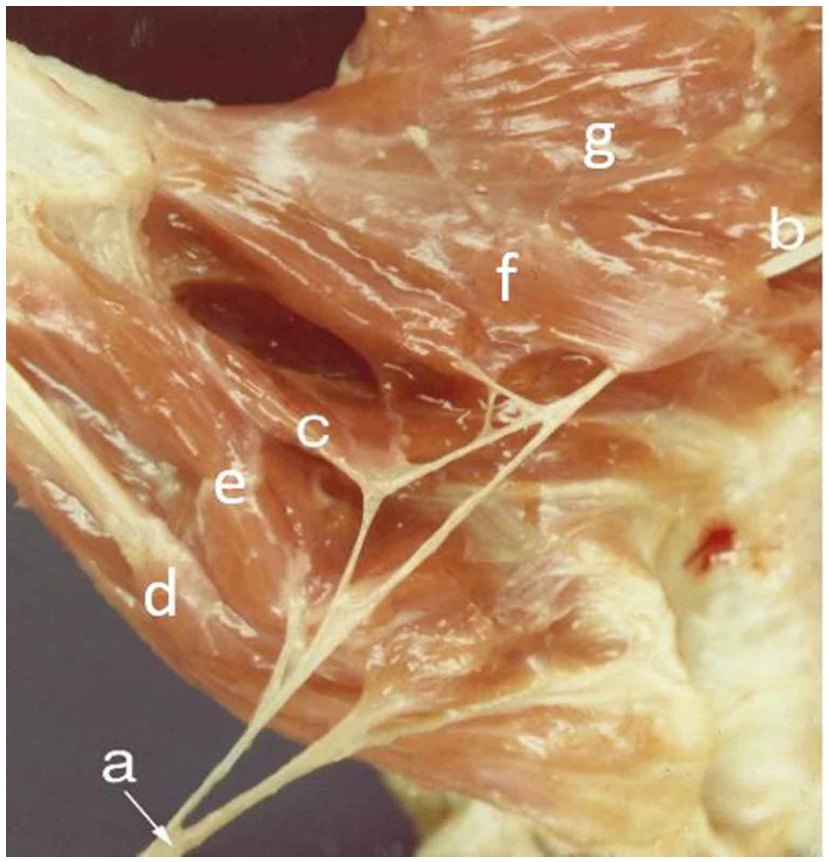

Fig. 6. Intramuscular e extramuscular anastomoses; (a) Recurrent branch of median nerve; (b) Deep branch of ulnar nerve; (c) Deep head of FPB (double innervation); (d) Abdutor pollicis brevis; (e) Superficial head of FPB; (f) Oblique head of Adutor pollicis muscle; (g) Transverse head of Adutor pollicis muscle. nerve in 66 (82\%) of dissected hands (Fig. 1), in 14 (17.5 $\%$ ) had a double innervation (Fig. 7). The transverse head of adductor pollicis was innervated exclusively by deep branch of ulnar nerve in 77 (96.4 \%) (Fig.1) in $3(3.6 \%)$ had a double innervation. (Fig. 8).

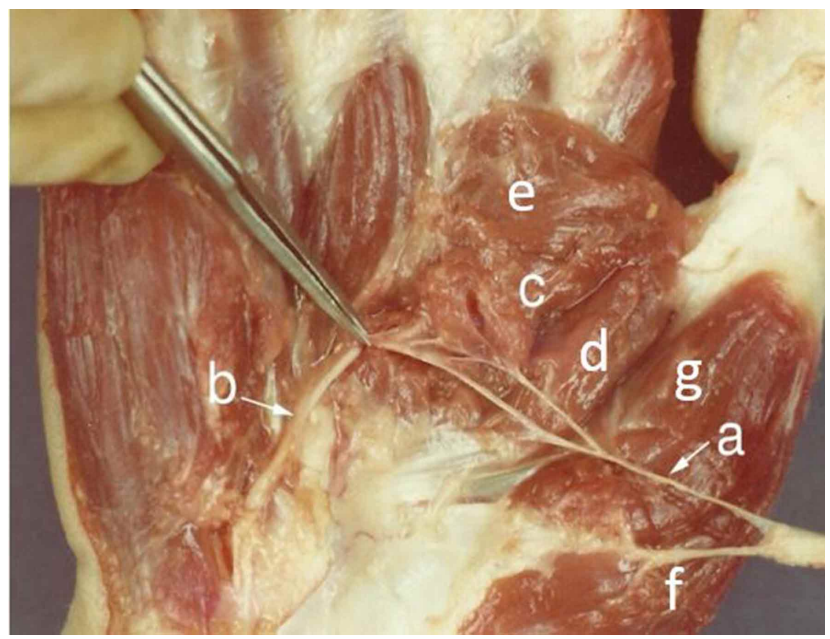

Fig.7. Intramuscular e extramuscular anastomoses; (a) Isolated branch of median nerve; (b) Deep branch of ulnar nerve; (c) Oblique head of FPB (double innervation); (d) Deep head of FPB; (e) Transverse head of Adutor pollicis muscle; (f) Abdutor PB; (g) Superficial head of FPB.

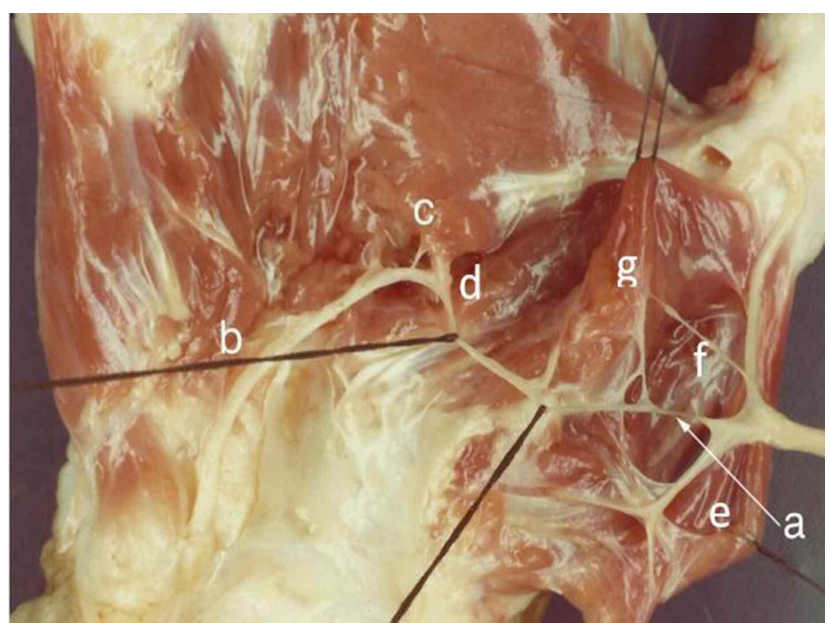

Fig. 8. (a) Recurrent branch of median nerve; (b) Deep branch of ulnar nerve; (c) Transverse (c) and oblique head (d) (double innervation; (e) Abdutor pollicis brevis muscle; (f) Oponens pollicis muscle; (g) Superficial head of FPB; Deep head of FPB (absent). 
CAETANO, E. B.; VIEIRA, L. A.; NAKAMICHI, Y. C.; SAWADA, M. M.; ANDRADE, A. A. \& NAKASONE, M. T. Anastomosis between the deep branch of ulnar nerve and a branch of the median nerve (Cannieu-Riche anastomosis) and thenar muscles innervation. Anatomical study and clinical implications. Int. J. Morphol., 36(1):7-13, 2018.

According to our study the pattern of innervation more frequent in relationship to the thenar muscles are the following: The AbPB and the OP muscle are innervated exclusively by branches of median nerve. The flexor pollicis brevis muscle should be considered as a normal pattern. This is that superficial head of FPB receives innervation of branches of median nerve, and the deep head receives innervation from deep branch of ulnar nerve and branches of median nerve (dual innervation). The oblique and transverse heads of AdP are innervated by ulnar nerve.

\section{DISCUSSION}

The incidence of Cannieu-Riché anastomosis is a controversial matter. There is great discrepancy in the literature regarding the prevalence rates of the CRA. Cannieu dissected 23 hands and identified anastomosis in three (13 $\%)$. In the same year, Riché (1897) described three types of connections: Type I, between the deep branch of ulnar nerve and the branch of the median nerve, destined to both heads of the FPB; Type II, between the deep branch of ulnar nerve and the median nerve within the belly of the transverse head of the adductor pollicis; Type III, between these two nerves within the belly of the lumbrical muscle. In a study combining EMG and percutaneous nerve stimulation, Forrest concluded that CRA should be much more common than we can imagine and also stressed the frequency of anomalous and double innervation of the thenar muscles. Harness \& Sekeles (1971) found CRA in 28 of 35 dissected hands (77 $\%)$. Souza (1975) dissected 60 embalmed cadaver hands and found CRA in 30 hands (50 \%). In an EMG study, Kimura et al. (1983) detected an incidence of $83.3 \%$ (125 out 150) in the hands of unselected living participants. Falcone and Spinner found this neural communication in three of 10 dissected hands (30\%). Homma \& Sakai (1992) found RCAs in four of six dissected hands $(66.6 \%)$, and Budak \& Gönenç (1999) found CRA in 1 of 32 hands. Ajmani (1996) dissected 68 hands from 34 cadavers, and 13 of the 68 hands exhibited anastomoses between the ulnar and median nerves. Bölükbasi et al. (1999) reported that no CRAs were found in 108 electrophysiologically evaluated medical students $(0$ out of 216 hands). However, in a retrospective analysis of 870 patients who had been examined for upper limb focal neuropathies via electroneuromyography, the prevalence of CRA was found to be $1.4 \%$. In an extensive meta-analytic study of the anastomoses of the upper limbs, Roy et al. analyzed 501 cases from 6 studies and found a prevalence rate of CRA of $55.5 \%$. These authors emphasized that the incidence of CRA could potentially be higher if finer dissection techniques and fresh cadavers were used to avoid missing the smaller anastomotic fibers. According to Yang et al. (2016), CRAs were observed in 45 of 90 cadaveric upper limbs $(50 \%)$.

Harness \& Sekeles studied 19 prepared and 16 freshly dissected specimens and did not detect CRA anastomoses in eight of 35 hands. These authors explained that it was possible that the fibers originating from the ulnar nerve through this anastomosis were so small that the CRA could not be anatomically detected. They further suggested that CRAs would have been noted in all of the dissected hands, if finer dissecting techniques and fresher fresh specimens had been used. In the 16 fresh specimens, they found anastomoses. Kimura et al. detected this anastomosis in 83 $\%$ of the hands of 150 unselected living participants. Their results led them to assume that perhaps the use of more sensitive electrophysiological techniques, such as recording with needle electrodes, a higher percentage of the detection of this anastomosis between the ulnar and median nerves in the hand would have been found. Our findings confirm the discussion from Harness \& Sekeles and Kimura et al. We found this neural communication in all 80 of the dissected hands $(100 \%)$. Careful dissections of fresh cadavers under high magnification (a surgical microscope at 10 to $16 \mathrm{X}$ ) were performed to permit fine dissections. In some cases the anastomotic branch was so small that magnification of $16 \mathrm{X}$ was necessary for visualization. We agree with these authors that the strong electrophysiological and anatomical evidence of a neural communication may imply that CRA should be perceived as a normal anatomical neural connection and not as an anatomical variation.

According to Chevrier (1904), the median nerve fascicles from this anastomosis arises laterally to the flexor pollicis longus tendon, when originating from the motor branch and medially, when originating from the collateral digital nerve of the thumb. Souza found CRAs between the deep branch of ulnar nerve and a branch of the median nerve in $50 \%$ of cases, and between the deep branch and ulnar nerve and a collateral digital nerve of the median nerve in $50 \%$ of cases that were always lateral to the flexor pollicis longus tendon. Falcone \& Spinner (1985) found CRAs in three instances; two were lateral and dorsal to the flexor pollicis longus tendon; the third arose from a separate branch of the median nerve that ran dorsal and medial to the tendon of the flexor pollicis longus. In our findings, the branches originating from the median were always lateral and dorsal to the tendon of the flexor pollicis longus, and passed between the tendon and the first metacarpal. Branches originating from the motor branch were observed in 35 hands (70\%), separated branches of the median nerve was observed in 24 hands $(30 \%)$, the collateral radial nerve of the thumb in $17(21.5 \%)$, and from the common collateral digital nerve it was found in 4 hands $(5 \%)$. We did not find anastomotic 
CAETANO, E. B.; VIEIRA, L. A.; NAKAMICHI, Y. C.; SAWADA, M. M.; ANDRADE, A. A. \& NAKASONE, M. T. Anastomosis between the deep branch of ulnar nerve and a branch of the median nerve (Cannieu-Riche anastomosis) and thenar muscles innervation. Anatomical study and clinical implications. Int. J. Morphol., 36(1):7-13, 2018.

branches originating from the digital palmar branch of the index finger in our dissections as described by Sarikcioglu \& Sindel and Paraskevas et al. (2010).

The double innervation of each thenar muscle suggests the incidence of CRA. Forrest supposition that muscles situated in close proximity to anastomotic branches and supplied by them, have a double innervation, was supported by Harness $\&$ Sekeles, they conclude that terminal motor anastomoses between the median and ulnar nerves might be more frequent than had been reported. Our findings agree with this statement, we found double innervation of deep head of FPB in 52 out 80 hands $(65 \%)$ in 11 the deep head were absent $(14 \%)$. The superficial head was double innervated in 24 out $80(30 \%)$ hands, oblique head of adductor pollicis in in 14 hands (17.5 $\%)$ a transverse head in 3 hands (3.6\%). Brooks (1886) emphasized the double innervation of this muscle, he found double innervation in 19 of his 31 specimens $(61 \%)$. He further noted 5 specimens in which both divisions of FPB were innervated purely by the ulnar nerve. Highet reported a series of 20 median nerve lacerations and 25 ulnar nerve lacerations, analyzing the function of FPB. He found it to be present in 16 of 20 median nerve injuries and in 24 of 25 ulnar nerve injuries. Additionally, he described four cases of complete median nerve laceration in which the OP appeared to be a normal function, and one case in which action of the FPB, OP, and APB were undisturbed. Cliffton (1948) examining a large number of patients with peripheral nerve injury. It was surprising to find cases in which the innervation of intrinsic muscles remained despite total lesion of median or ulnar nerve. Rowntree (1949) in a large series of World War II injuries, examined 102 median nerve lacerations and 124 ulnar nerve lacerations supplemented with electrical stimulation, and local procaine nerve block. He found that the FPB evidences dual innervation in $15.5 \%$ of cases. Sala (1958) studied the innervation of FPB and OP using electrical stimulation in 30 patients with neurological disease, the FPB received double innervation by median and ulnar nerve in $74 \%$ (3 hands out of every 4 examined) and OP in $32 \%$ the hands. Day \& Napier (1961) found double innervation of the deep head of FPB in 5 out of 24 hands, and, in 7 out of 30 hands, of the superficial head of the same muscle. When they performed the dissection according to Brooks' method, Day \& Napier found double innervation of both, the deep and superficial heads of the FPB in $20 \%$ of cases. Forrest \& Basmajian (1965) found that the superficial head of the flexor pollicis brevis, received double innervation by ulnar and median branches in 17 out of 25 cases. Forrest used electromyography and nerve stimulation to study variation in the motor supply about the thumb, stimulating the median, ulnar, and radial nerves and recording from the thenar muscles. His findings are remarkably similar to those of Highet in showing that in 17 of 25 cases $68 \%$. The FPB received dual innervation by median and ulnar nerves and also 5 out of 20 showed some dual innervation of the OP. Sarikcioglu \& Sindel during dissection, found a communication between the digital branch to the index finger and branch to the AdPM. Thus, terminal communications between motor nerves may provide muscles with double motor innervation, and are important for motor innervation of the hand, particularly thenar muscles. This variant should be kept in mind during surgery, electrophysiological examinations of the hand. Souza, reports a series of 60 dissected embalmed hands, the AbPB and the OP muscle are innervated exclusively by the branch of median nerve in all dissected hands. Falconer \& Spinner describe in 10 dissected hands the median nerve motor branch gave the only observed supply to the AbPB and OP. Ajmani found double innervation of FPB in $35 \%$ and double innervation of OP in $9 \%$ of 68 hands. In 6 hands where the deep head was absent, the superficial head of FPB was supplied purely by the ulnar nerve. Forrest found that the opponens pollicis had double motor innervation in $20 \%$ of his cases, while Sala found it in one third of his cases. Harness $\&$ Sekeles using the same electromyography technique used by Sala, found the frequency of double innervation of the opponens pollicis in $(77 \%)$ and report that the reasons for this large discrepancy are not clear. It should be noted that the validity of these results, depends rather critically on whether or not impulses are picked up from the flexor pollicis brevis. We can therefore, conclude that the results of anatomical dissections are much more reliable through electrical stimulation studies. In our 80 hands we found that the AbPB and the OP muscle are innervated exclusively by median nerve branches in all dissected hands. The superficial head of flexor pollicis brevis was innervated by the median nerve branches in 56 hands (70 \%) of the hands. In $24(30 \%)$ it had double innervation (from branches of median nerve and deep branch of ulnar nerve). The deep head of flexor pollicis brevis was absent in 11 hands (14\%), in 52 hands (65\%), occurred a double innervation, in $14(17.5 \%)$ exclusively by deep branch of ulnar nerve and $3(3.6 \%)$ exclusively by a branch of median nerve. The oblique head of adductor pollicis muscle was innervated only by deep branch of ulnar nerve in 66 hands $(82.5 \%)$ of dissected hands, in $14(17.5 \%)$ had a double innervation. The transverse head of adductor pollicis was innervated exclusively by deep branch of ulnar nerve in 77 cases $(96.4 \%)$, in $3(3.6 \%)$ had a double innervation.

CAETANO, E. B.; VIEIRA, L. A.; NAKAMICHI, Y. C.; SAWADA, M. M.; ANDRADE, A. A. \& NAKASONE, M. T. Anastomosis entre el ramo profundo del nervio ulnar y un ramo del nervio mediano (anastomosis de Cannieu-Riché) e inervación de la eminencia tenar. Estudio anatómico e implicaciones clínicas. Int. J. Morphol., 36(1):7-13, 2018.

RESUMEN: El objetivo de este trabajo fue informar la anastomosis entre el ramo profundo del nervio ulnar y un ramo del 
CAETANO, E. B.; VIEIRA, L. A.; NAKAMICHI, Y. C.; SAWADA, M. M.; ANDRADE, A. A. \& NAKASONE, M. T. Anastomosis between the deep branch of ulnar nerve and a branch of the median nerve (Cannieu-Riche anastomosis) and thenar muscles innervation. Anatomical study and clinical implications. Int. J. Morphol., 36(1):7-13, 2018.

nervio mediano (Anastomosis de Cannieu-Riché) y de la inervación de los músculos de la eminencia tenar. Se realizó la disección anatómica de 80 miembros de 40 cadáveres adultos frescos en el Departamento de Anatomía de la Facultad de Medicina de la Universidad Católica de São Paulo, Brasil. Se estudió la incidencia de formación de la ACR y la inervación de los músculos tenares. La ACR se encontró en todas las manos disecadas (100\%). El músculo abductor corto del pulgar y el músculo oponente del pulgar recibían inervación exclusivamente por el nervio mediano en todas las manos disecadas. La cabeza superficial del músculo flexor corto del pulgar estaba inervada por el nervio mediano (70 \%), en 24 casos, (30\%) presentó inervación doble (nervio mediano y ramo profundo del nervio ulnar). La cabeza profunda del músculo flexor corto del pulgar estuvo ausente en 11 manos $(14 \%)$, mientras que en 52 manos $(65 \%)$ se produjo una doble inervación. En 14 casos (17,5\%) se vio inervado exclusivamente por el ramo profundo del nervio ulnar y en 3 manos $(3,6 \%)$ exclusivamente por un ramo del nervio mediano. La cabeza oblicua del músculo aductor del pulgar estaba inervada sólo por el ramo profundo del nervio ulnar en 66 manos (82\%), en 14 casos $(17,5 \%)$ tenía una doble inervación. La cabeza transversa del músculo aductor del pulgar estaba inervada exclusivamente por el ramo profundo del nervio ulnar en 77 manos (96,4\%), en 3 manos $(3,6 \%)$ presentó una doble inervación. De acuerdo con nuestro estudio, el patrón de inervación más frecuente en relación al músculo flexor corto del pulgar debe ser considerado como un patrón normal, en el que la cabeza superficial recibe inervación de ramos del nervio mediano y la cabeza profunda recibe inervación del ramo profundo de nervio ulnar y ramos del nervio mediano (inervación dual). El músculo abductor corto del pulgar y el músculo oponente del pulgar recibieron inervación exclusivamente por el nervio mediano. Tanto la cabeza oblicua como transversa del músculo aductor del pulgar están inervadas exclusivamente por el nervio ulnar. La ACR se encontró en todas las manos disecadas $(100 \%)$.

PALABRAS CLAVE: Nervio mediano; Nervio ulnar; Mano; Inervación.

\section{REFERENCES}

Ajmani, M. L. Variations in the motor nerve supply of the thenar and hypothenar muscles of the hand. J. Anat., 189(Pt. 1):145-50, 1996.

Bölükbasi, O.; Turgut, M. \& Akyol, A. Ulnar to median nerve anastomosis in the palm (Riches-Cannieu anastomosis). Neurosurg. Rev., 22(23):138-9, 1999.

Brooks, H. S. J. Variations in the nerve supply of the flexor brevis pollicis muscle. J. Anat. Physiol., 20(Pt. 4):641-4, 1886.

Budak, F. \& Gönenç, Z. Innervation anomalies in upper and lower extremities (an electrophysiological study). Electromyogr. Clin. Neurophysiol., 39(4):231-4, 1999.

Cannieu, A. Recherche sur l' innervation de l'eminence thenar par le cubital. J. Med. Bord., 1896. pp.377-9.

Chevrier, G. Note sur 1'anastomose de Riche et Cannieu. Bull. Mem. Soc. Anat. Paris, 1904. pp.16.

Cliffton, E. E. Unusual innervation of the intrinsic muscles of the hand by median and ulnar nerve. Surgery, 23(1):12-31, 1948
Day, M. H. \& Napier, J. R. The two heads of flexor pollicis brevis. J. Anat., 95(Pt. 1):123-30, 1961.

Falconer, D. \& Spinner, M. Anatomic variations in the motor and sensory supply of the thumb. Clin. Orthop. Relat. Res., (195):83-96, 1985.

Forrest, W. J. \& Basmajian, J. V. Functions of human thenar and hypothenar muscles: An electromyographic study of twenty-five hands. J. Bone Joint Surg., 47(8):1585-94, 1965.

Forrest, W. J. Motor innervation of human thenar and hypothenar muscles in 25 hands: a study combining electromyography and percutaneous nerve stimulation. Can. J. Surg., 10(2):196-9, 1967.

Gupta, S. \& Michelsen-Jost, H. Anatomy and function of the thenar muscles. Hand Clin., 28(1):1-7, 2012.

Harness, D. \& Sekeles, E. The double anastomotic innervation of thenar muscles. J. Anat., 109(Pt. 3):461-6, 1971.

Highet, W. B. Innervation and function of the thenar muscles. Lancet, 241(6234):227-30, 1943

Homma, T. \& Sakai, T. Thenar and hypothenar muscles and their innervation by the ulnar and median nerves in the human hand. Acta Anat. (Basel), 145(1):44-9, 1992.

Iyer, V. \& Fenichel, G. M. Normal median nerve proximal latency in carpal tunnel syndrome: a clue to coexisting Martin-Gruber anastomosis. $J$. Neurol. Neurosurg. Psychiatry, 39(5):449-52, 1976.

Kimura, I.; Ayyar, D. R. \& Lippmann, S. M. Electrophysiological verification of the ulnar to median nerve communications in the hand and forearm. Tohoku J. Exp. Med., 141(3):269-74, 1983.

Paraskevas, G.; Ioannidis, O. \& Martoglou, S. Cannieu-Riche anastomosis of the ulnar to median nerve in the hand: case report. Chirurgia (Bucur), 105(6):839-42, 2010.

Riché, D. Le nerf cubital et les muscles de l'eminence thenar. Bull. Mem. Soc. Anat. Paris, 72:251-2, 1897

Rowntree, T. Anomalous innervation of the hand muscles. J. Bone Joint Surg. Br., 3lB(4):505-10, 1949

Roy, J.; Henry, B. M.; Pekala, P. A.; Vikse, J.; Saganiak, K.; Walocha, J. A. \& Tomaszewski, K. A. Median and ulnar nerve anastomoses in the upper limb: A meta-analysis. Muscle Nerve, 54(1):36-47, 2015.

Sala, E. Electromyographic study of the innervation of the flexor brevis and opponent musclesof the thumb. Riv. Patol. Nerv. Ment., 80:131-9, 1958.

Sarikcioglu, L. \& Sindel, M. A variant of the Cannieu-Riche communication: case report. Morphologie, 86:35-7, 2000

Souza, O. M. Contribuição ao Estudo da Inervação dos Musculi Hipotenares et Tenaris no Homem. Thesis. São Paulo, Escola Paulista de Medicina, 1975.

Yang, H.; Gil, Y.; Kim, S.; Bang, J.; Choi, H. \& Lee, H. Y. From the brachial plexus to the hand, multiple connections between the median and ulnar nerves may serve as bypass routes for nerve fibres. J. Hand Surg. Eur. Vol., 41(6):648-56, 2016.

\author{
Corresponding author: \\ Edie Benedito Caetano \\ Department of Orthopedics of the Catholic \\ University of São Paulo \\ São Paulo \\ BRAZIL
}

Email: ediecaetano@uol.com.br

Received: 18-07-2017

Accepted: 11-10-2017 